\title{
Tourism and sexual violence and exploitation in Jamaica: contesting the 'trafficking and modern slavery' frame
}

\section{KATIE CRUZ, JULIA O'CONNELL DAVIDSON and JACQUELINE SANCHEZ TAYLOR}

Abstract: The US TIP Report frames Jamaica as having a problem with 'human trafficking' and 'child sex tourism'. This paper presents preliminary findings from our mixed methods research on Jamaicans' experience of working in the sex trade and in the formal and informal tourism economy. In brief, though our sex worker research participants routinely face violence in the course of their work, they were not driven into sex work and are not prevented from exiting it by 'human traffickers', but rather by economic need and, in the case of male and trans sex workers, by anti-gay prejudice. Our participants view the criminalisation of sex work and of homosexuality as far more urgent and significant threats to their safety and well-being than 'human trafficking'. Criminalisation and marginalisation were also pressing concerns for our non-sex-worker interviewees, and the paper uses these data to critically interrogate the lines that are drawn between work, slavery, and freedom in this dominant, Global North discourse.

Keywords: Trafficking, sex work, criminalisation, violence, anti-gay prejudice, Jamaica.

\section{INTRODUCTION}

'How we frame social issues profoundly influences our understanding of them, and how we think and talk about solutions', Kendall-Taylor and Gibbons (2018) observe. Framing, they argue, involves more than naming a social problem. It is what we leave unsaid, as well as what we choose to say; it is the tone in which we say it; and the metaphors, visuals, and statistics marshalled to describe the issue. Taken together, such elements generate a frame that powerfully shapes national and international policy discourse and practice. This has certainly been the case with regard to the forms of 
exploitation and suffering framed as 'trafficking' and 'modern slavery'. Emerging from a concern with transnational organised crime (O'Connell Davidson 2015), the 'trafficking and modern slavery' frame focusses attention on the individuals involved in crime (the victims and the perpetrators) and identifies law, law enforcement, and victim protection and support, as key to solving the problem. To the extent that civil society organisations, mainstream businesses, and members of the public can help combat 'trafficking and modern slavery', it is by contributing to state efforts to identify the crime and so assist law enforcement with prosecution, and by supporting and/or orchestrating efforts at victim protection and crime prevention.

This article draws on data from our British Academy funded research on child sex tourism in Jamaica to consider the limitations of the 'trafficking and modern slavery' frame as applied to our Jamaican interviewees' accounts of their own experiences (both as children and as adults) of sexual and other violence, and sexual and labour exploitation. Re-framed through the eyes of our interviewees, the problem and possible solutions to it look very different from the picture circulated by anti-trafficking and anti-modern-slavery actors. For, whilst our interviewees' experiences of violence and exploitation do indeed often link both to law and law enforcement practice, as well as to the tourism industry, they do so in ways that, for a variety of reasons, are left unsaid by those promoting 'the trafficking and modern slavery' frame.

\section{TRAFFICKING AND MODERN SLAVERY AS DEFINED IN LAW}

Trafficking is often described as a criminal offence that involves the recruitment, or arrangement for the movement, of people in conditions of non-consent and exploitation. Legal definitions are considerably more complex. In 2000, an international agreement on transnational crime was drafted and a treaty within the resulting UN Convention on Transnational Crime is the Protocol to Prevent, Suppress and Punish Trafficking in Persons, Especially Women and Children (UN 2000). This places a mandatory obligation on signatory states to criminalise instances of trafficking. The protocol defines trafficking as the act of recruitment, transportation, transfer, or receipt, by means of threats, force, coercion, abduction, fraud, deception, or the abuse of power or vulnerability (the presence of which vitiates consent to the act and any intended purpose), for the purpose of exploitation, including 'the exploitation of the prostitution of others or other forms of sexual exploitation, forced labour or services, slavery or practices similar to slavery'. Only one of the listed 'means' and 'purpose' need be present for an 'act' to constitute trafficking. The relevant 'act' need not involve the arrangement or facilitation of border crossing or, indeed, involve any movement or transportation. Recruitment alone will suffice. When evidence of at least one of 
these 'means' is present, any consent to both the 'act' and the 'purpose' is deemed legally irrelevant. However, what constitutes the means that vitiate consent, including 'force', 'coercion', and 'abuse of vulnerability', is not elaborated upon in the protocol. The meaning of 'exploitation of prostitution' and 'sexual exploitation' is also left unresolved.

The result is an instrument open to differing interpretations about the parameters of consent - which scholars and activists argue is made totally irrelevant or irrelevant only when force, violence, deception, etc. are present-and 'sexual exploitation', including whether and how the latter differs from exploitation in other labour markets (Dempsey 2017, Dempsey et al. 2012, Doezema 2005, Halley et al. 2006, Hoyle et al. 2011, Kotiswaran 2014, Munro 2005). The broad drafting of the protocol helps explain the divergent criminal justice approaches taken in domestic legal regimes. The US Trafficking Victims Protection Act (TVPA) and the UK Modern Slavery Act (MSA) are cases in point.

The US TVPA defines 'severe forms of trafficking in persons' as 'the recruitment, harboring, transportation, provision, or obtaining of a person for the purpose of a commercial sex act' which is 'induced by force, fraud, or coercion, or in which the person induced to perform such an act has not attained 18 years of age' or 'the recruitment, harboring, transportation, provision, or obtaining of a person for labor or services, through the use of force, fraud, or coercion for the purpose of subjection to involuntary servitude, peonage, debt bondage, or slavery'. In US federal law, then, there is a difference between 'trafficking' and other crimes, such as rape, child sexual abuse, and offences related to prostitution in any country's law (such as owning or managing a brothel), even though these other crimes may feature in each case of trafficking. There is also a difference between 'trafficking' and forms of labour exploitation that may fall foul of a given country's employment law (such as failing to pay the minimum wage) but to which a worker has agreed without the use of force, fraud, or coercion. In other words, not every case of rape or child sexual abuse, and not every case in which workers, including sex workers, labour in poor or hazardous conditions for extremely low pay, is a 'severe form of trafficking in persons' ${ }^{1}{ }^{1}$ US federal law therefore interprets the UN Protocol as making consent relevant unless extreme forms of coercion are used in both the 'act' and 'purpose' stages of 'trafficking', and as distinguishing between exploitation in commercial sex and other forms of labour.

\footnotetext{
${ }^{1}$ Hence, a country whose government has a truly abysmal record on prosecuting rape, such as the United States, can nonetheless be applauded by the TIP Office for demonstrating serious and sustained efforts to eliminate trafficking (According to the Rape, Abuse, and Incest National Network (RAINN), only 13 out of 1,000 cases of sexual assault get referred to a prosecutor).
} 
The United Kingdom's MSA has created an offence of 'human trafficking'. The 'act' of human trafficking is the arrangement and facilitation of another person's travel, including arrival, departure, or movement within any country. Arrangement and facilitation can include recruitment, transferring or transporting, harbouring or receiving, or exchanging control of a person. Unlike the TVPA, consent to any of these 'acts' is explicitly irrelevant. The 'purpose' of trafficking is labelled 'exploitation', which encompasses Article 4 of the European Convention on Human Rights (so slavery, servitude, or forced or compulsory labour) or sexual exploitation. Like the TVPA, then, the MSA makes a distinction between 'human trafficking' and other crimes and wrongs, including both sexual offences and labour violations. Unlike the TVPA, the MSA requires evidence of coercion in relation to the 'purpose' of labour exploitation but not in the context of sexual exploitation. The result is that 'human trafficking' for the purpose of sexual exploitation is a very broad offence. It includes facilitating the movement of a sex worker within the United Kingdom by recruiting her for employment in the sex industry, through to facilitating the movement of a person into the United Kingdom by use of threats of physical violence and deception and subjection to debt-bondage in the sex industry. In both situations there is no legal requirement to demonstrate lack of consent at the 'act' or 'purpose' stage. On the other hand, 'human trafficking' for the purpose of labour exploitation requires evidence of grave and punitive actions on the part of the exploiter at the 'purpose' or 'exploitation' stage of the offence. UK law therefore interprets the UN Protocol somewhat differently to the TVPA by making consent relevant only to the question of whether a person is exploited in the final, labour stage of the 'trafficking' process.

The way in which the United States interprets the Trafficking Protocol has had, and continues to have, an impact well beyond its own borders. Casting itself in the role of the world's moral police, the United States' Congress has given a mandate to the Office to Monitor and Combat Trafficking in Persons 'to issue annual Trafficking in Persons (TIP) reports that rates each country's progress on eliminating trafficking' (Desyllas 2007: 66). The TIP Report ranks other nations in tiers according to their degree of compliance with the standards set by the TVPA, and threatens 'underperforming' nations with sanctions (O'Brien \& Wilson 2015: 124). Compliance hinges on legislation that criminalises and severely punishes 'human trafficking', measures to encourage law enforcers to investigate 'trafficking' cases and public prosecutors to prosecute them, and efforts to provide victims with a range of services. The United States has consistently awarded itself and several other Global North countries a Tier-1 ranking, and has equally consistently censured many Global South countries, including Jamaica, regarding their efforts to combat 'human trafficking'.

The global significance of the terms 'trafficking' and 'modern slavery' has recently been reinforced by their inclusion in the United Nations' Sustainable Development 
Goals (UN 2015), the eighth of which (SDG 8) aims to achieve 'decent work for all', but includes a target (Target 8.7) requiring 'immediate and effective measures to eradicate forced labour, end modern slavery and human trafficking, and secure the prohibition and elimination of the worst forms of child labour' by 2030. But though pressure on Global South countries to demonstrate their commitment to combatting 'trafficking' and 'modern slavery' looks set to continue, it remains unclear what precisely they are supposed to combat. As the above brief discussion of the legal intricacies of those terms demonstrates, (a) while it has become common sense to subsume trafficking within slavery, slavery is in fact an element of trafficking; (b) domestic legal regimes are framing both 'trafficking' and 'slavery' in different ways, all of which are permitted by the UN Protocol; and (c) without further definition, it is far from clear, at least in legal terms, what is being referred to as 'modern slavery' and 'human trafficking', including in SDG Target 8.7. As we will argue below, though Jamaica has repeatedly been described as having a serious problem with 'trafficking' and 'modern slavery', both the narrow approach of the TVPA and the broad approach of the MSA fail to capture the realities, abuses, and needs of those who participated in our research.

\section{JAMAICA'S BEEN FRAMED}

Jamaica has consistently been criticised by the United States as regards its government's efforts to combat 'human trafficking'. In 2005, it was placed on the Tier-3 list of countries whose governments are adjudged not to comply fully with what the US State Department takes as the minimum standards for the elimination of trafficking (set out in the TVPA), and are not considered by the State Department to be making sufficient effort to do so. The ranking put Jamaica at risk of losing much-needed foreign (non-humanitarian) aid from the United States, and inflicted reputational damage. Whether or not the Jamaican government accepted the TIP evaluation and framing of the problem in 2005 (see JIS 2015), it had little choice but to take the forms of action demanded by the United States. It therefore initiated a National Awareness Campaign in August of that year, which faithfully reproduced the frame that informs the US State Department's understanding of the problem of 'trafficking' and the solutions to it. It also created a National Task Force against Trafficking in Persons (NATFATIP), a Legislative Task Force to review existing laws that affect child labour and victim assistance and a National 'Trafficking in Women and Children Special Unit' to investigate cases of commercial sexual abuse (Shared Hope International 2007).

In 2007, a Trafficking in Persons (TIP) Act was enacted, prohibiting all forms of 'trafficking in persons' and related offences, such as financially benefitting from 
'trafficking crimes'. Over the next decade, in the name of combatting trafficking, law enforcement agents have undertaken raids on establishments where commercial sexual services are sold, and conducted clampdowns on street sex work. The government also responded to TIP reporting demands for victim protection by creating a Trafficking in Persons' shelter, and later requiring the NATFATIP to identify other shelter locations (JIS 2013). It established a Child Advocate and the Child Development Agency has worked with non-governmental organisations (NGOs) to extend and develop services for 'victims of trafficking' and children 'at risk of trafficking', including The HEART programme which Shared Hope International (2007) describes as offering 'exploited and at-risk youth, who have left school, a certificate in a vocational skill which will allow them to survive independently and keep them from becoming victims in the commercial sex markets'.

The Jamaican government continues to expend precious resources on efforts to meet the demands imposed by the US TIP Office. In fiscal year 2017/18, the Ministry of Justice allocated 34.8 million Jamaican dollars (US\$272,470) for anti-trafficking efforts; training on trafficking continued to be provided to police officers, and the Office of the Director of Public Prosecutions maintained a nineteen-person trafficking unit (US State Department 2017). A Specialised Unit at the Office of the Director of Public Prosecutions to deal with trafficking cases has been established, a sixteen-seater Toyota bus, valued at approximately US\$6 million has been donated to the Anti-Trafficking in Persons Squad of the Jamaica Constabulary Force by the Ministry of Justice so that "victims of human trafficking now have a convenient and secure mode of transport to take them to safe shelters' (JIS 2017). In April 2018, Jamaica became the first Caribbean country to join the Blue Heart Campaign Against Human Trafficking, turning on blue lights at three locations in Kingston to symbolically demonstrate the government's commitment to 'the struggle against modern slavery' (UNODC 2018).

Despite making all the above efforts, Jamaica has never been ascribed Tier-1 TIP ranking. Since 2006, the country has merely oscillated between Tier-2 and the Tier-2 Watch List, the threat of Tier-3 punishment always hanging over it. Year after year, the TIP Report's Jamaica country narrative claims that it is a source and destination country for adults and children subjected to 'sex trafficking' and forced labour. There is an emphasis on domestic as well as international 'sex trafficking', and repeated reference to 'child sex tourism' as a problem. In 2018, the government was upbraided for the fact that it 'did not report any investigations, prosecutions, or convictions of foreign tourists for the purchase of commercial sex acts from child trafficking victims' and it was urged to increase its efforts in this area. In 2017 and 2018, the fact that many children are reported missing in Jamaica is noted in TIP Reports, followed by the claim that 'some of these children are subjected to forced labor or sex trafficking'. 
Though prosecutions have been made under trafficking law, the small number is taken as evidence that the government is making insufficient efforts to combat trafficking, rather than that the crime is less prevalent than had been assumed, or that the 'trafficking' frame distorts our understanding of the problem, and the solutions to it.

Below, we question the 'trafficking and modern slavery' framing by drawing on data from our research in Jamaica. In addition to background interviews with police officers, hotel managers and workers, representatives of NGOs, and tourists, and a survey of 82 tourists, our field research has included focus group interviews and a workshop with 15 adult sex workers, in-depth narrative biographical interviews with 24 former child labourers who had experienced one or more of the following: labour exploitation, physical violence, rape, and trading sex for material and/or financial benefits. It was our privilege to work on this project with the Sex Work Alliance of Jamaica (SWAJ), a grassroots NGO run by and for sex workers, and SWAJ is currently conducting a survey of adult sex workers in several parishes, with 70 respondents so far.

Our sample is small, and purposive rather than representative. The value of our data is not that they allow us to make claims about the numerical scale of any given problem, but rather that they offer an insight into the lives of individuals who experience the forms of exploitation and violence that are commonly discussed under the rubric of 'trafficking and modern slavery'. This in turn allows us to contextualise and critically interrogate claims made about people like our interviewees in dominant policy and NGO discourse on 'trafficking and modern slavery'.

\section{REFRAMING THE PROBLEM FROM BELOW}

The 'trafficking and modern slavery' frame has been widely embraced and heavily promoted by groups and individuals who enjoy a good deal of political, economic, and institutional power (O'Connell Davidson 2015). It clearly 'makes sense' to business leaders, such as those involved in the Global Business Coalition Against Human Trafficking (gBCAT), which includes Coca-Cola, ExxonMobil, Ford, Microsoft, and Manpower Group amongst its members, and to political leaders of the affluent world no matter their political outlook (Trump is as keen to endorse the anti-trafficking and modern slavery cause as was Obama), as well as to international agencies such as United Nations Office on Drugs and Crime (UNODC) and International Organization for Migration (IOM), and the many small and large NGOs in the Global North and Global South that secure grants and charitable donations to fund their anti-trafficking and modern slavery work. The appeal of this frame to those already privileged by the global status quo lies in what it does not, as well as what it does, say. 
For instance, poverty is frequently referenced as a factor relevant to 'trafficking' and 'modern slavery'. What remains unsaid is that poverty is not a 'thing', but a concept, 'a word we use to describe the state of people not having enough resources. It is 'the condition of being poor', a politico-legal phenomenon, like the condition of others being rich' (Howard 2013). The history of the global politics that place many ordinary Jamaicans in that condition dates back to colonisation and slavery (Rose 2002, Sherlock \& Bennett 1998, Williams 1961), the legacies of which continue to reverberate to this day. In the 20th century, Jamaica lacked economic autonomy, with foreign decision-makers influencing the course of its economy:

partly as a result of the historical experience of foreign ownership and control over important sectors of the economy, and partly because of the country's dependence on financial assistance from individual countries and multilateral organisations such as the IMF and World Bank (Kirton 1992: 13).

Jamaica was the first Caribbean country to turn to the International Monetary Fund (IMF) for assistance in 1977, and forty-one years later, it remains dependent on regular agreements from the IMF to stabilise its economy. The policy packages tied to those loans are imposed with a view to ensuring that Jamaica can service its international debt, not to ensuring that the government can pursue economic or welfare policies that might assist its people. In 2011/12, 80 cents out of every dollar earned by the country was spent to pay back loans and debt service charges, (Scott 2018). In 2013, though Jamaica had already repaid over US\$1.3 billion more than it had been loaned by the IMF, the country was offered a US $\$ 1$ billion ( $£ 650$ million) loan to help meet huge debt payments due in coming years, again accompanied by austerity measures, including a pay freeze, amounting to a 20 per cent real-terms cut in wages (Dearden 2013). Government capital expenditure was reduced and the economy shrank. Debt repayments amounted to twice what is spent on education and health combined. The poverty rate doubled between 2007 and 2014. Infant mortality rates increased and the number of children completing primary school declined. After decades of IMF 'rescue' interventions in Jamaica, Dearden (2013) notes, 'There has been no progress in cutting hunger, or increasing basic water and sanitation provision.'

This is the economic context in which the island's tourist industry has been developed since the late 1970s, and whilst it goes unremarked in US TIP Report country narratives and in mainstream policy discourse on 'trafficking and modern slavery', it was central to our Jamaican interviewees' narratives about their lived experience, the risks they faced, and the choices they made. 


\section{TOURISM WORK, SLAVERY, AND FREEDOM}

Tourism is vitally important to Jamaica's economy. It employs over 277,000 both directly (in hotels, transport, attractions, and craft), and indirectly (trading, manufacturing, banking, etc.) mainly in and around resort towns (World Travel and Tourism Council 2017), and generated 27.2 per cent of Jamaica's GDP in 2014 (World Travel and Tourism Council 2015). The Ministry of Tourism regards tourism development as central to the strategy by which Jamaica 'will progress to become developed over the next 21 years' (Ministry of Tourism 2018). To this end, efforts to attract local and foreign investors by identifying suitable tourism sites for the development of more resorts and attractions, and by fast-tracking the approval process for tourism development projects have been made (JAMPRO 2016), and the government hopes to see still greater expansion of the industry. In the words of Edmund Bartlett (2018), Minister for Tourism:

The resilient tourism sector continues to be the leading catalyst of economic development in Jamaica ... generating one in every four jobs and forging many critical sectoral linkages that produce positive spill over effects for the wider local and Caribbean economy.

It is certainly true that tourist development has created jobs in Jamaica. However, as in the Caribbean more generally, the heavy presence of transnational conglomerates as owners of large hotels, booking companies, transportation links, and tour operators 'reinforces the asymmetrical distribution of power and economic resources between former colonies of the Caribbean (periphery) and their European (core) colonizers' (Sealy 2018, Taylor 2003). Moreover, aside from noting problems of leakage (it is estimated that around 'one third of Jamaica's tourism revenue is lost in leakages' (Gordon \& Harris 2015)) and tax avoidance by the big tourism players (Ambrosie 2015), to evaluate the benefits of the industry to the island's people, it is important to consider its social, economic, and environmental impact, and of particular importance to this article, the kind of work and employment tourism creates.

Tourist development in Jamaica, as in the Caribbean more generally, has overwhelmingly created low-waged, precarious jobs (Mullings 1999). Indeed, many commentators liken low-paid workers toiling in tourism 'to the monoculture plantation workers during the colonial days, in which workers are compensated minimally' (Wong 2015: 11; see also O’Neal 2012), a comparison sharpened by the trend towards developing enclave, all-inclusive (AI) beach resorts. Growth in tourist arrivals has not altered this trend. Between 2007 and 2012, for example, the share of rooms reserved taken by large AI hotels, as opposed to villas, guest houses, and apartments, remained constant, at 55 per cent, versus 26 per cent. AIs also outperformed 'traditional' model 
hotels in terms of average occupancy rates -67 per cent against just 40 per cent (Gordon \& Harris 2015).

The AI model is designed to ensure that the highest possible percentage of all tourists' spend on their Jamaican holiday goes through the hotel and booking company (with both often owned by same parent company). Tourists who go AI not only purchase their room and all meals from the hotel, but are also encouraged to book every other element of their holiday - day trips, snorkelling and water sports, shopping expeditions, etc. - - through the hotel, often prior to departure. The AI tourist is, in this way, largely isolated from local markets, and the growth of this type of tourism does not, therefore, expand the livelihood opportunities of Jamaicans who are not employed by the large, AI hotels or their suppliers (i.e., independent taxi drivers, watersports operators, guides, craft-sellers, masseuses, hair-braiders, restaurant owners and workers, etc.)

Even those who manage to secure employment in AIs do not necessarily fare well. In 2017, Secretary-General of the United Nations World Tourism Organization (UNWTO), Taleb Rifai, described all-inclusive resorts as 'similar to modern-day plantations' (Loop 2017). That remark resonated with interviewees who worked or had worked in AIs, many of whom, without prompting, made a connection between tourism and slavery, though not the connection that is made in 'trafficking and modern slavery' discourse. Some commented on the AIs as an extension of the relations of slavery under which 'house' slaves served their white masters and mistresses, and told us that many who have worked in Sandals' resorts say that the company's name is actually an acronym for 'Slave All Niggers Daily At Low Salary'. One interviewee described having been given a trainee bartender position when he was nineteen. The position was unpaid. The only benefit that trainees receive is meals whilst working, and they are forbidden from accepting tips from customers. 'I think that ... they look at it as they are giving us a privilege and advantage', our interviewee explained, because they provide trainees with 'work experience' that in theory will improve their prospects in the highly competitive job market. He worked for two months without pay in the hope that they would offer him a permanent position at the end of the traineeship. Instead, they 'let him go', and took on the next trainee to perform unwaged labour for the vastly profitable corporation.

In some AIs, as well as in 'regular' hotels, a sizeable portion of the staff are on precarious contracts, hired for three or six months, then 'let go' for two weeks before being rehired, thereby enabling the employer to evade employment legislation requiring them to pay for employee benefits. Such workers thus have no entitlement to sickness or maternity rights and benefits, or to a pension. Housekeepers and bartenders in AIs and other hotels often receive only the national minimum wage, for which they are expected to work shifts that often extend beyond the mandated eight 
hours, and sometimes six days per week. The minimum wage rose from 6,200 to 7,000 JMD per week in 2018 (Henry 2018), but even for those in regular employment covered by this legislation, this is not a living wage. The government's inability to spend on infrastructure, education, health, and welfare makes the lives of its poorer citizens much more difficult and expensive. There is, for example, little public transport, so that to get children to and from school and to travel to work typically means taking taxis, and we interviewed working mothers who spent half of their weekly wage on taxi fares for themselves and their children. One mother of five told us that she earned 2500 JMD daily as a hotel housekeeper, but was not guaranteed regular days of employment_- 'I work whenever time I am requested to be at work ... if there's no guests, like it's a bit slow, I [am] at home.' To get to work required her to take two cabs, costing her 670 JMD daily. When she had to leave her younger children at the day-care centre in order to work, it cost her 700 JMD per day per child.

Though schooling is in theory free, in practice, parents have to pay for books, equipment, and uniforms as well as providing each child with 'regular bus fare, back and forth, and lunch money. ... You're looking at like 1000 dollars for one child that is in high school, per day', as one mother explained. Rent, water, electricity, and basic foodstuffs are expensive in Jamaica. Indebtedness is a constant risk. Several of our tourism employee interviewees told us they had had to take out emergency loans at high interest to pay water or electricity charges, or property tax on land where they lived in order to avoid eviction and homelessness.

Because they struggle to pay for basic necessities, our tourism worker interviewees often invoked the metaphor of slavery. For them, working simply to be able to survive to the next day in order to work again, without being able to save or plan for the future, was like slavery in the sense of being nothing more than a beast of burden:

I think that slavery is not abolished ... [You're] working a regular nine to five, but you're ... a slave because you don't earn anything for yourself. You send yourself back to work, you buy food yourself to go back to work, pay rent and then all the money is gone.

24-year-old man

[In the past] people marched and they burned courthouses down, [because they] wanted to be independent, not be slaves. And even today it's the same thing happening ... it's like you work and work and you're not free, you can't save, you can't think of owning a proper house, you can't send your kids to school. You know, the basics.

37-year-old woman

It is also important to note that where the 'trafficking and modern slavery' frame assumes a firm line between 'good' or 'decent and respectable' jobs in the formal tourism sector and the experience of those in what Shared Hope International (2007: 1) terms 'the marketplace of commercial sexual exploitation', our interview data suggest 
that the division is not clear cut. Interviewees told us that sexual harassment of both female and male hotel workers, by supervisors and managers as well as by tourists, is commonplace, and that workers fear they will lose their jobs if they report it. ${ }^{2}$ In some cases, they said that a manager or supervisor had demanded sex under threat that they would terminate the worker's employment unless he or she complied. In other cases, they reported that management tacitly communicated an expectation that workers should not complain about sexual harassment by tourists, or even that workers, especially those employed in 'entertainment' roles, should acquiesce to sexual advances from tourists.

Because those who work in hotels as housekeepers, bar and waiting staff, security guards, porters, and grounds workers are often unable to support themselves and their families on their wages, tips are an important source of revenue. This also serves as a disincentive to complain about sexual harassment and an incentive to comply with demands for sexual contact. Our interview data challenge the assumption that there is a clean dichotomy between safe, non-sexually-exploitative employment in the formal tourism sector, and unsafe and sexually-exploitative work in nightclubs and on the streets. In fact, some of our sex worker focus group participants observed that they would rather get paid for sex than be forced to give sexual favours for free in order to keep hold of a poorly paid job. Data from our interviews with sex workers also challenge the 'trafficking and modern slavery' frame in other respects.

\section{'SEX TRAFFICKING', SEX WORK, RAPE, AND CONFINEMENT: ADULTS}

Sex work is far from being a safe way in which to earn a living in Jamaica. The adult sex workers (female, male, and trans) who participated in our research reported frequently experiencing rape, assault, extortion, and robbery. Several of our female sex worker interviewees had also experienced confinement and constant surveillance for periods of time in nightclubs that are fronts for brothels. None, however, had as adults experienced 'sex trafficking' as defined in the TVPA. All of them had made an

\footnotetext{
${ }^{2}$ Two police officers we interviewed described a case in 2016 in which two male tourists filmed themselves forcing a clearly distressed young woman to perform 'deep throat' oral sex until she vomited, then insulting and abusing her for her stupidity in having eaten before arriving as she knew in advance what they expected of her. The video was then circulated on social media. When it came to the police's attention, they discovered that the woman was aged above eighteen, and employed as a housekeeper at the hotel at which the tourists were staying. The video made it clear that she had consented to have sex with them for money, the police officers said, and as she was not under-age, there was no reason to investigate further. They did not believe it possible that the encounter could have started consensually but then become non-consensual - in their view, if a woman consents to sexual contact for money, she is fair game for whatever follows.
} 
independent choice to engage in sex work as a means of earning money, and given the wider economic and employment context described above, the choice looks economically rational. Where the minimum wage in Jamaica is $7000 \mathrm{JMD}$ per week, it is possible for sex workers to earn upwards of 10,000 JMD on a good day. Our interviewees were not being induced to provide commercial sex acts by means of force, fraud, or coercion. The violence that they experience is not used to force them into becoming a sex worker, but rather is used against them because they are sex workers.

Street sex work in Jamaica is criminalised through soliciting and loitering laws, and our data confirm what other research has found, namely that some police officers use physical violence against sex workers, and/or rape them, and/or demand sexual favours, and/or extort money from them (Amnesty International 2016, Mullings 1999, SWAJ 2016). Out of 70 sex worker survey respondents, 65 stated that they had experienced violence or its threat from police officer. Because sex work is stigmatised, and male and trans sex workers doubly so, and because sex workers can expect no protection from the police, street sex workers are also at high risk of violence from members of the public, as well as being targets for robbery (91 per cent of survey respondents had experienced violence or its threat from members of the public; 95 per cent had been robbed while doing sex work). Last but not least, street sex workers and sex workers who solicit custom via the internet (a method that is especially widely used by male sex workers due to the stigma that attaches to homosexuality) are at risk of rape and assault by their presumed clients. All our male and several of our female sex worker interviewees reported having experienced, often multiple times, being subjected to terrifying ordeals including gang rapes, by individuals posing as customers. In the survey, 88 per cent stated they had been raped at work. Again, such violence was not employed to induce them to sell sexual services - they were quite willing to perform commercial sex acts - but rather to force them into non-consensual sexual acts. They were victims of rape and battery, not trafficking as defined by the UN Protocol or the TVPA.

Moreover, they were unable to access justice or protection, because the criminalization of prostitution, and in the case of male interviewees, also of homosexuality, meant they dared not report the crimes perpetrated against them. The interviews we conducted with five police officers, two very senior, suggest sex workers were right to believe that reporting rape and assault to the police would be pointless and risky. Asked what their response would be if an adult sex worker approached them to report being raped, each police officer we interviewed stated that 'prostitutes cannot be raped'. When they complain of rape, they simply mean they have not been paid, and by engaging in prostitution, they are committing a crime, police offers told us. The two senior officers laughed aloud at the question.

The very high risk of violence from police, passers-by, and clients that street sex workers face is relevant to understanding the experience of those adult women sex workers 
who reported having experienced periods of confinement in brothels. Nightclubs in Jamaica often employ dancers, and in some cases, the dancers are expected or permitted to sell sexual services as well as dance. Where nightclubs double as brothels, the owner takes a cut from each transaction between sex worker and client. Clearly, this would be impossible if sex workers were free to make arrangements to meet clients off premises, after the club closed. To ensure that the club gets its cut, dancers are often therefore required to sign up for two-week-long contracts, during which time they must live on the club premises, so that all commercial sexual acts take place on the premises. Having signed up for the fortnight, dancers are not normally allowed to leave the club unaccompanied. As one interviewee explained, if she needed to go anywhere at all whilst on a contract, even just to go into town to buy personal items, she was escorted by club personnel, in a club-owned vehicle, and under constant surveillance.

For a significant, but temporary, period of time then, the club employer imposes extensive restrictions on the freedoms of women workers. Nonetheless, these employment relations can be actively chosen, because when working in nightclubs, women are not exposed to the same risk of violence that they face on the streets. As another interviewee put it, a sex worker in Jamaica can have freedom but no safety, or safety but no freedom. The women we interviewed knew the terms of the agreement they enter into with the club owner; they entered it without force or coercion; and the fortnight-long contracts do not constitute involuntary servitude, peonage, debt-bondage, or slavery.

In short, the adults we interviewed who currently worked as sex workers experienced multiple and serious violations of civil, labour, and human rights on a routine basis, but none were victims of a 'severe form of trafficking in persons', as defined in the TVPA. The solutions that flow from the 'trafficking and modern slavery' frame do nothing whatever to address the violations they experience, and may in fact worsen their situation by adding to the stigma of sex work, licensing more intensive and punitive police clampdowns on street sex workers, as well as raids on nightclubs, in the name of combatting 'trafficking'.

\section{SEX TRAFFICKING, HOMOPHOBIA, SURVIVAL: CHILDREN}

Does the framework work better in relation to the experience of children, defined as persons under the age of eighteen? Below, we limit our discussion to boys, because all eight of the adult male and trans participants in our focus group and biographical narrative interviews started to trade sex as children, and we have not yet had time to analyse data from women who started sex work under the age of eighteen. 
Laws criminalising homosexuality were introduced to Jamaica by the 19th-century British colonial authorities, and:

Jamaica's 'buggery law' still reads like the original 1861 British law. Article 76 of the Offences Against the Person Act, entitled the 'Unnatural Crime,' says, 'Whosoever shall be convicted of the abominable crime of buggery [anal intercourse] committed either with mankind or with any animal, shall be liable to be imprisoned and kept to hard labour for a term not exceeding ten years' (Offences Against the Person Act 2009). Article 77 goes further, making the attempt to engage in 'buggery' or 'indecent assault' on a male punishable by seven years with or without hard labour ... the law also makes it illegal for 'male persons' to engage in or attempt to engage in 'acts of gross indecency,' in public or private, a misdemeanour offence punishable by two years in prison with or without hard labour (Offences Against the Person Act 2009, a. 79) (Gaskins 2013: 432).

The criminalisation of homosexuality and widespread, extremely negative responses to gay people in the country (Lovell 2016, West \& Cowell 2014) played a driving role in our male interviewees' entry into sex work when under the age of eighteen. In childhood (aged between twelve and sixteen), they had been identified as gay by members of their family and/or community and were, as a result, subjected to bullying, violence - up to and including rape - and rejection. Some were thrown out by parents or guardians ('I grew up in a family that is very homophobic and when my story came out, it wasn't easy, I was beaten, I was told to leave the community'); others ran away. Whether they were expelled or ran away, they found themselves without money or shelter. Aged sometimes as young as thirteen, and even if closer to seventeen, lacking the school matriculation certificate that is required by most employers, there was no possibility of finding a regular job. They therefore turned to sex work as a means of survival, or, in one case, that of 'Kevor', avoided homelessness by accepting an older man's offer of a place to stay. This led to a relationship within which the older man provided material support to Kevor but in exchange, expected him to be constantly available for sex. Eventually, Kevor found this relationship so oppressive that he turned to sex work as a means by which to support himself independently.

Though widely known as a country where anti-gay prejudice is strong, it is also the case that Jamaica has a queer community, and this is of huge importance to gay and trans youth who have run away or been expelled from home (Mills 2017). Those cast out of 'respectable' society, which can include straight female sex workers as well as people who are LGBT, often offer each other friendship, care, and support. 'We see each other as family', one interviewee explained, and continued:

If like a bunch of us is living in one house, the older one will be housemother, the others will be sister, brother, cousin, we just have a family. We are a small community so we just make it a family. 
Sex work is not necessarily the economic mainstay of, or even present at all in, such families/communities, but nonetheless it can feature. 'Candy', a trans interviewee who had been thrown out of home and was sleeping on the streets aged fifteen, described having been shown kindness and concern by a 22-year-old woman sex worker. 'I told her everything and she took me in', Candy told us, 'she was the one who feeds, shelters and clothes me for about three or four years'. This woman did introduce Candy to street sex work, in that she told her 'you can come where I work and you can get a little money', and directed customers looking for anal sex to Candy. Through the lens of the 'trafficking and modern slavery' frame, she would therefore appear as a 'trafficker'. Yet she did not take money from Candy, and in Candy's words:

She gave me an option, she was not forcing me, she was just showing me around and what I could do to benefit some money for myself, to put myself back into school and I could make the decision. ... I'd say that ... it was good doing that, because if I didn't, I don't know where I would be right now. So I'd say I made a good decision that day.

One interviewee had been deceived and exploited by someone he thought was offering him friendship. Aged thirteen and already experiencing community rejection on the basis of his perceived homosexuality, 'Brandon' was pleased to find acceptance of his sexual orientation by a young man at least ten years older than he was. One day, however, the older man arranged for Brandon to provide commercial sexual services to a group of male tourists. Brandon was not aware of what had been arranged until they arrived and his 'friend', who had taken payment from the men, introduced Brandon to them. It was only because one of the tourists gave Brandon a tip of US $\$ 100$ that he earned anything at all from this experience of being, in effect, gang raped. Brandon subsequently began to independently make arrangements to sell sex. When the violent homophobia of his extended family led him to run away from home aged fifteen, sex work became his only source of subsistence, and he found support and an alternative, chosen, family/community amongst others in a similar situation to his own.

As children, our interviewees did experience violence whilst working. As with adult sex workers, this violence came from individuals who posed as customers but then raped and assaulted them, from police officers, and from homophobic strangers passing in the street. In a context where both prostitution and homosexuality are criminalised, however, children as well as persons over the age of eighteen are often afraid, or believe it would be pointless, to report even the most violent attacks and rapes to the police. ${ }^{3}$ But it is important to note that, apart from when Brandon was

${ }^{3}$ A 2011 incident in which heavily armed police officers raided a gay club in Montego Bay, terrorising and beating its patrons (Gaskins 2013) offers one example of why gay youth are unlikely to turn to the police for assistance. 
tricked and forced by his 'friend', his and our other interviewees' involvement in commercial sex as children was not orchestrated or controlled by any third party. Indeed, the idea, promulgated by Evangelical NGOs such as Shared Hope International (2007, 2012), that demand for sex with children is encouraging 'traffickers and facilitators' to lure teenagers into the commercial sex market overlooks the realities of the supply side. ${ }^{4}$ Our interviewees were not enticed away from a happy childhood and into a hopeless life of neglect, abuse, and violence. In fact, our interviews with non-sex worker adults who had experienced labour or sexual exploitation when under the age of eighteen, as well as with sex workers, challenge the dichotomy commonly assumed in anti-trafficking and modern slavery discourse between the safety of home and school for children, and the dangerous terrain of the world beyond it.

Six of the men we interviewed who do not self-identify as sex workers, and who are heterosexual, had also run away from home as young teenagers (in one case at the age of ten). They made their way to tourist areas, where they became involved in a wide range of informal livelihood strategies, ranging from producing and selling crafts and trinkets, through selling marijuana, to befriending tourists, in some cases entering into sexual-economic exchanges with tourist women (see also Kempadoo 2004).

${ }^{4}$ In 2015, the Jamaican Ministry of Justice contested TIP report allegations that child sex tourism is a problem in Jamaica's resort areas, noting that the government:

has no knowledge, record or information to support any activities that could be described as 'sex tourism' as defined by the United Nations. There is no information to suggest that the structure or network of the tourism industry facilitates a sex tourism trade in Jamaica. No specific instances of 'sex tourism' are cited in the Report, and none has been disclosed to the Government (JIS, 2015).

We should note that, whilst some interviewees told us that they had sold sex to, or been raped by, tourists when under the age of eighteen, we found nothing in our research, and can find no independent research evidence, to support the idea that Jamaica attracts tourists seeking sexual access to children. TIP reports provide little or no information about their methodology or the evidence upon which their rankings are based. The reports typically list 'the types of organizations from which it gets information. ... However, no information is given to indicate how (or if) these reports are vetted, verified, or weighed against other sources' (Esarey 2015). In the case of allegations about child sex tourism, TIP reports suggest that information was garnered from 'NGOs and other local observers'. If so, it is concerning to note that one of the main international NGOs active in the field of 'trafficking' in Jamaica is Shared Hope International (SHI), one of a number of US Evangelical groups that put pressure on the Bush administration in the early 2000s to take up the anti-trafficking cause, and that has benefitted from the millions of dollars subsequently allocated by Attorney-General John Ashcroft in grants to faith-based anti-trafficking groups (Soderlund 2005: 76). In 2006, SHI produced a documentary and report on sexual exploitation in Jamaica which cited the US TIP report as a source of evidence that sex trafficking is a problem in the country and also involved a sting operation that was represented as evidence of the crime it had staged, and it has continued to publish claims that 'rampant sex tourism in Jamaica compromises youth safety' (SHI, 2012). 
Through the lens of 'trafficking and modern slavery' discourse, running away made them vulnerable to trafficking and commercial sexual exploitation. But they were, in fact, equally vulnerable to abuse and exploitation at home. They came from poor families, and described extremely abusive and violent adult carers. They had worked from the age of five or six, some in the home and yard, helping to grow food and to take care of younger siblings, some on small farms where their labour supplemented that of adults (see Ennew 1982). One man told us he had been left with his grandfather's new wife, and:

she take a hate to me. I do most work in the yard. Everything they call on me. ... I was the first one in the yard that could grate and wash a cassava, grating cassava from the age of seven year old to make bammy... They were selling the bammy in Montego Bay and Kingston. ... Growing up, they said I was a bad boy. Never give no trouble, just seven years old growing up, what could I do? ... I was hungry. ... she liked to beat me. I hate it.

As was the case for gay youth discussed above, running away to the beach and relying on the goodwill of local people and tourists to survive was, for boys and girls from homes like these, perceived at the time and retrospectively as a better and a safer option than remaining at home. In the words of one interviewee, 'I run away! I run away and I went to the wrong road, but it was the right road.' Despite their very real vulnerability to a range of forms of exploitation, violence, and abuse in tourist areas, rescuing and returning such children home would certainly have been no guarantee of freedom from such rights violations. Nor would removing them into the care of the Jamaican state. In 2010, reporting on his mission to Jamaica, the UN Special Rapporteur on torture and other cruel, inhuman, or degrading treatment or punishment observed that children are detained if they are deemed in need of care and protection, as well as if deemed uncontrollable or in conflict with the law:

I found children of all three categories held together without distinction. It is of great concern that there is in the legislation no clear definition or criteria for the identification of an uncontrollable child. The wide discretion currently allowed to the judiciary has led to a relatively high number of detentions of children under such orders. In addition, many children seem to receive disproportionally long sentences for minor infractions (UN 2010).

Though he commented on one example of good practice, he also noted that his visit to the St. Andrew Juvenile Remand Centre for boys in Stony Hill 'demonstrated a disturbing system of repression and regular corporal punishment. The boys on remand were never allowed to leave the buildings, depriving them of any recreational activities in the open air' (UN 2010). One of our interviewees, now aged eighteen, described being subjected to horrific punishments when held in a children's home, including being forced to kneel for hours on gravel in the beating sun, arms outstretched 
and holding heavy stones. In 2015, Hyacinth Samuels, mental health officer and coordinator of child and adolescent mental health services for Jamaica's North East Regional Health Authority, observed that many children's homes are run along the lines of penal institutions, rather than care homes:

Children do not see these places as being caring, they say that they're being punished and oftentimes the staff are like warders. ... The abuse they get before they go into these homes continue after they go into the homes, and I can recall doing summer camp with ... many girls coming to us and saying 'Miss why would they lock us up when the people who are abusing us are allowed to walk free.' (quoted in Hibbert 2015).

\section{CONCLUSION}

There is no doubt that the people we interviewed in Jamaica, and others like them, deserve better, and that change is urgently needed if they are to be able to enjoy the basic rights and freedoms that are, in theory, the estate of all humankind. The question is whether the kind of measures that current concerns about 'trafficking and modern slavery' prompt are likely to promote such change. So far as the law is concerned, the TIP report urges the Jamaican government to concentrate on the prosecution of 'traffickers'. Yet from our female sex worker interviewees' viewpoint, the legal change that is required in order to better protect them from violence and exploitation is the decriminalisation of sex work. It is because prostitution is criminalised that they accompany customers to secluded spots where they are vulnerable to assault, and that they have no recourse to justice when attacked. It is because prostitution is criminalised that the police are able to harass and maltreat them, and so on. Equally, from the perspective of our male and trans interviewees who entered sex work as children, the problem with law and law enforcement is not simply or always that Jamaican governments have been lax with regard to efforts to prosecute and prevent what the US TVPA defines as 'severe forms of trafficking in persons'. For them, the more pressing problem is that governments have continued to uphold colonial-era laws against homosexuality. These laws 'foster and perpetuate an environment in which all people engaging in same-sex intimacy are marginalised' (Human Dignity Trust 2014). That environment leads directly to gay and trans teenagers' dependence on sex work as a means of survival, and it further strips gay and trans sex workers of protection against rape whilst working.

The 'trafficking and modern slavery' frame generates an equally questionable view of how the tourism industry is, and is not, implicated in the forms of violence and exploitation experienced by our interviewees. The emphasis on criminality means that 
problems described as 'child sex tourism' and 'sex trafficking' are imagined as bracketted off from ordinary, lawful business practices. It is assumed that, once made aware of these hidden scourges, tourism business actors and 'ordinary' tourists will become allies in the struggle to eliminate them. The child rights NGO ECPAT, supported by United Nations Children's Fund (UNICEF) and the World Trade Organization (WTO), thus established a Code of Conduct in 2004, which sets out business principles that travel and tour companies can voluntarily sign up to implementing with a view to preventing 'child sex tourism and trafficking of children' (ECPAT USA 2017). ${ }^{5}$ Educational and awareness-raising materials have been produced with a view to training hotel workers and tourists themselves to 'spot the signs', and then to report suspicions of trafficking and child sexual exploitation to the authorities. The NGOs promoting such materials are keen to emphasize that tourism businesses have nothing to lose and plenty to gain by supporting efforts to combat child sex tourism. As UNICEF Executive Director Carole Bellamy put it when the Code was launched in 2004: 'It is a win-win situation. Taking a firm stand against child sex tourism will attract consumers who are looking for ethical travel operators' (UNICEF 2004).

This is very much in line with mainstream corporate social responsibility (CSR) that thinking on how businesses should respond to 'trafficking and modern slavery' more generally. Indeed, Steve New's (2015: 7) comments on Walk Free's (2014) handbook, Tackling Modern Slavery in Supply Chains: A Guide 1.0 are equally applicable to the Code. He observes that the handbook:

serves as an illustration par excellence of a corporate approach to modern slavery that is based around routinized CSR best practice. It is difficult to find fault with any particular element, and difficult not to imagine that if firms were to follow the guidance presented, the world would be a much better place.

However, he continues, 'the document is also interesting in terms of what it does not say' (emphasis added), and the absences he identifies are equally pertinent to the

${ }^{5}$ By signing the code, the hotel and travel industry commit themselves to:

- Establish an ethical corporate policy against commercial sexual exploitation of children

- Train personnel in the country where children are sexually exploited

- Introduce clauses in contracts with suppliers, stating a common repudiation of sexual exploitation of children

- Provide information on the sexual exploitation of children to travellers

- Provide information to local 'key persons' at destinations

- Report annually (UNICEF 2014). 
relationship between the tourism industry and our Jamaican interviewees' experience of exploitation and violence as children and as adults:

it does not ask questions about the social or political conditions that give rise to vulnerable, precarious labour in the first place: the advice presented frames modern slavery as an evil which is exogenous to the corporations, and not as something that might be connected with the underpinning economic systems which support the 'good' firms. The report does not consider how the actions of the buying firms-for example, relentless cost cutting and the exercise of brutal commercial power-might stimulate supplying firms to feel the need to engage in, or turn a blind eye to, exploitative labour practices in the first place. There is also no discussion of how the people who are the victims of forced labour and modern slavery might be empowered to move beyond passive victimhood (2015: 8).

The 'trafficking and modern slavery' frame reduces the complex realities of the lives of people like our interviewees into a narrative of almost fairytale simplicity about evil criminals preying on the innocent and gullible. It is a framing that hones in on the moment when one individual takes advantage of another individual's vulnerability, ignoring all of the structural factors that have, over time, worked to bring those two individuals together in this particular context and that have created the asymmetry of power that allows one to exploit and abuse the other. In Jamaica, this means ignoring the ways in which international debt and other aspects of international and national law condition 'the universe of possibilities that determine the degree of economic compulsion individuals confront' when deciding whether or not to enter or to remain in a given job or form of income generation (Steinfeld 2001: 23).

The 'trafficking and modern slavery' frame renders uncomplicated what is, in reality, an enormously complex policy field: one that spans welfare, housing, education, tourism development, employment, as well as criminal justice, and one fraught with contradictions and political dilemmas for anyone concerned with rights and freedoms. ${ }^{6}$ To have any hope of the kind of change that would improve the lives of our interviewees, we need to reframe the problem in a way that encourages politicians and policy makers to address, rather than sidestep, these complexities and contradictions.

\footnotetext{
${ }^{6}$ The latter are perhaps especially keenly felt by those campaigning for the decriminalisation of homosexuality in Jamaica from outside the country who find themselves 'caught between white queer homonormative racism and Anglo-Caribbean homo-hatred' (Walcott 2009).
} 


\section{Acknowledgements}

We are indebted to the British Academy for funding the project on which this article is based ('Revisiting child sex tourism, rethinking business responses', Award Ref: TS170020), and to our research partners, the Sex Work Alliance of Jamaica. We would also like to thank Cecily Jones for jointly conducting six interviews, and transcribing two of them. Julia O'Connell Davidson is also grateful to participants at the ESRC GCRF funded workshop 'Migration, Exploitation, Gender, Race, and Violence: Beyond Anti-Trafficking in the Americas' in Mexico City 2018 (Award Ref: ES/ P006906/1), who helped her think through the relationship between violence and harassment in mainstream workplace and sex work.

\section{REFERENCES}

Ambrosie, L. (2015), 'Tax Avoidance Through Vertical Integration', Tourism Watch, available at https:// www.tourism-watch.de/node/2517 [accessed 8 March 2019].

Amnesty International (2016), "I Feel Scared All the Time.” A Jamaican Sex Worker Tells Her Story'. https://www.amnesty.org/en/latest/news/2016/05/apple-sex-worker-testimony-jamaica/ [accessed 8 March 2019].

Bartlett, E. (2018), 'Tourism has Benefits for All', Jamaica Gleaner, 11 February. http://jamaica-gleaner.com/article/focus/20180211/edmund-bartlett-tourism-has-benefits-all

Dearden, N. (2013), 'Jamaica's Decades of Debt are Damaging its Future', The Guardian, 16 April. https://www.theguardian.com/global-development/poverty-matters/2013/apr/16/jamaica-decades-debtdamaging-future

Dempsey, M. (2017), 'What Counts as Trafficking for Sexual Exploitation? How Legal Methods Can Improve Empirical Research', Journal of Human Trafficking, 3(1): 61-80. https://doi.org/10.1080/23322705.2017.1280325

Dempsey, M., Hoyle, C. \& Bosworth, M. (2012), 'Defining Sex Trafficking in International and National Law: Mind the Gaps', Emory International Law Review, 26(1): 137-62.

Desyllas, M. (2007), 'A Critique of the Global Trafficking Discourse and U.S. Policy', The Journal of Sociology and Social Welfare, 34(4): 57-79.

Doezema, J. (2005), 'Now You See Her, Now You Don't: Sex Workers at the UN Trafficking Protocol Negotiation', Social and Legal Studies, 14(1): 61-89. https://doi.org/10.1177/0964663905049526

ECPAT USA (2017), The Tourism Child-Protection Code of Conduct. https://www.ecpatusa.org/code/

Ennew, J. (1982), 'Family Structure, Unemployment and Child Labour in Jamaica', Development and Change, 13(4): 551-63. https://doi.org/10.1111/j.1467-7660.1982.tb00137.x

Esarey, D. (2015), 'New Outrage at Old Problems in the TIP Report'. https://humantraffickingcenter.org/new-outrage-at-old-problems-in-the-tip-report/ [accessed 8 March 2019].

European Convention on Human Rights. https://www.echr.coe.int/Documents/Convention_ENG.pdf

Gaskins Jr., J. (2013), “"Buggery” and the Commonwealth Caribbean: A Comparative Examination of the Bahamas, Jamaica, and Trinidad and Tobago', in C. Lennox \& M. Waites (eds), Human Rights, Sexual Orientation and Gender Identity in The Commonwealth: Struggles for and Change, Human Rights Consortium, Institute of Commonwealth Studies, 429-54.

Gordon, L. R. \& Harris, M. (2015), 'The Not So "All Inclusive” Tourism in Jamaica: Economic Linkages to Local Supply', Journal of International and Interdisciplinary Business Research, 2(1): 40-52. 
Halley, J. Kotiswaran, P., Shamir, H. \& Thomas, C. (2006), 'From the International to the Local in Feminist Legal Responses to Rape, Prostitution/Sex Work, and Sex Trafficking: Four Studies in Contemporary Governance Feminism', Harvard Journal of Law and Gender, 29(2): 335-423.

Henry, B. (2018), 'Increased Minimum Wage Takes Effect August 1', Jamaica Observer, 27 June. http://www.jamaicaobserver.com/news/increased-minimum-wage-takes-effect-august-1_137049? profile $=1373$

Hibbert, K. (2015), 'Review How Children Are Treated in State Care, Says Official', Jamaica Observer, 7 June. http://www.jamaicaobserver.com/news/review-how-children-are-treated-in-state-care--saysofficial_19077194

Howard, N. (2013), 'Forced Labour: It's About Politics Not Crime', The Guardian, 7 November. https://www.theguardian.com/global-development-professionals-network/2013/nov/07/ forced-labour-slavery-crime

Hoyle, C., Bosworth, M. \& Dempsey, M. (2011), 'Labelling the Victims of Sex Trafficking: Exploring the Borderland Between Rhetoric and Reality', Social and Legal Studies, 20(3) 313-29. https://doi.org/10.1177/0964663911405394

Human Dignity Trust (2014), 'Gareth Henry v Jamaica', available at http://www.humandignitytrust.org/pages/OUR\%20WORK/Cases/Jamaica [accessed 8 March 2019].

JAMPRO (2016), 'Jamaica Turns To "Shovel Ready" Programmes to Attract Tourism Investments', Do Business Jamaica, 3(1).

http://www.jamaicatradeandinvest.org/sites/default/files/resources/DoBusinessJamaicaIssue_ OCTOBER_2016.pdf [accessed 8 March 2019].

JIS (2013), 'Govt. Establishes Shelter for Victims of Human Trafficking', Jamaica Information Service. https://jis.gov.jm/govt-establishes-shelter-for-victims-of-human-trafficking/

JIS (2015), 'Jamaican Government Rejects Portions of 2015 Trafficking in Persons US State Department Report', Jamaica Information Service, 28 July.

https://jis.gov.jm/jamaican-government-rejects-portions-of-2015-trafficking-in-persons-us-statedepartment-report/

JIS (2017), 'Bus Donated to Jamaica Constabulary Force Anti-Trafficking in Persons Unit', Jamaica Information Service.

https://jis.gov.jm/bus-donated-jamaica-constabulary-force-anti-trafficking-persons-unit/

Kempadoo, K. (2004), Sexing the Caribbean: Gender, Race, and Sexual Labor (New York, Routledge). https://doi.org/10.4324/9780203338087

Kendall-Taylor, N. \& Gibbons, S. (2018), 'Framing for Social Change', Stanford Social Innovation Review, 21-23 February. https://ssir.org/articles/entry/framing_for_social_change

Kirton, C. (1992), Jamaica: Debt and Poverty (London, Oxfam).

Kotiswaran, P. (2014), 'Beyond Sexual Humanitarianism: A Postcolonial Approach to Anti-trafficking Law', UC Irvine Law Review, 4(1): 353-405.

Loop (2017), 'UNWTO Head Calls for Caribbean to Rethink All-inclusive Model', Loop Jamaica, 28 November.

http://www.loopjamaica.com/content/unwto-head-calls-caribbean-rethink-all-inclusive-model [accessed 8 March 2019].

Lovell, J. (2016), 'We Are Jamaicans:' Living With and Challenging the Criminalization of Homosexuality in Jamaica', Contemporary Justice Review, 19(1): 86-102.

https://doi.org/10.1080/10282580.2015.1101687

Mills, L. (2017), 'Dwayne Jones and the Dangers of Tragedy Tourism', Making Queer History, 24 February. https://www.makingqueerhistory.com/articles/2017/2/24/dwayne-jones-and-the-dangers-oftragedy-tourism [accessed 8 March 2019].

Ministry of Tourism (2018), 'Vision 2030 Jamaica: National Development Plan'.

https://www.mot.gov.jm/page/policies 
Modern Slavery Act 2015. (c.30) (London, The Stationery Office). http://www.legislation.gov.uk/ukpga/2015/30/contents/enacted

Mullings, B. (1999), 'Globalization, Tourism, and the International Sex Trade', in Sun, Sex and Gold: Tourism and Sex Work in the Caribbean (Oxford, Rowman and Littlefield), 55-81.

Munro, V. (2005), 'A Tale of Two Servitudes: Defining and Implementing a Domestic Response to Trafficking of Women for Prostitution in the UK and Australia', Social and Legal Studies, 14(1): 91-114. https://doi.org/10.1177/0964663905049527

New, S. J. (2015), 'Modern Slavery and the Supply Chain: The Limits of Corporate Social Responsibility?', Supply Chain Management: An International Journal, 20(6): 697-707. https://doi.org/10.1108/SCM-06-2015-0201

O'Brien, E. \& Wilson, M. (2015), 'Clinton, Bush and Obama: Changing Policy and Rhetoric in the United States Annual Trafficking in Persons Report', in M. Dragiewicz (ed.), Global Human Trafficking (London, Routledge), 123-39.

O'Connell Davidson, J. (2015), Modern Slavery: The Margins of Freedom (London, Palgrave Macmillan).

O'Neal, M. E. (2012), Slavery, Smallholding and Tourism: Social Transformations in The British Virgin Islands (New Orleans, LA, Quid Pro Books).

Rose, E. A. (2002), Dependency and Socialism in the Modern Caribbean: Superpower Intervention in Guyana, Jamaica, and Grenada, 1970-1985 (Lanham, MD, Lexington Books).

Scott, S. (2018), '2018 Marks 41 years of IMF "Rescue” of Jamaica', Jamaica Observer, 13 May. http://www.jamaicaobserver.com/news/2018-marks-41-years-of-imf-2018-marks-41-years-of-imf-8216rescue-8217-of-jamaica_132762

Sealy, W. (2018), 'From Colonialism to Transnationalism: The Neo-colonial Structure of Caribbean Tourism', presented at Tourism and Sustainable Development Conference, 16-18 May, Kathmandu, Nepal.

Shared Hope International (2007), 'Demand: A Comparative Examination of Sex Tourism and Trafficking in Jamaica, Japan, The Netherlands, and The United States'. https://childhub.org/en/child-protection-online-library/shared-hope-international-2007-demandcomparative-examination-sex [accessed 8-March 2019].

Shared Hope International (2012), 'Back to Our Beginning: Rampant Sex Tourism in Jamaica Compromises Youth Safety'. https://sharedhope.org/2012/05/back-to-our-beginning-rampant-sex-tourism-in-jamaicacompromisesyouth-safety/ [accessed 8-March 2019].

Sherlock, P. \& Bennett, H. (1998), The Story of the Jamaican People (Kingston, Ian Randle).

Soderlund, G. (2005), 'Running from the Rescuers: New US Crusades Against Sex Trafficking and the Rhetoric Of Abolition', NWSA Journal, 17(3): 64-87. https://doi.org/10.2979/NWS.2005.17.3.64

Steinfeld, R. (2001), Coercion, Contract and Free Labor in the Nineteenth Century (Cambridge, Cambridge University Press). https://doi.org/10.1017/CBO9780511549564

SWAJ (2016), 'Promoting Sexual Health and Human Rights', Sex Work Association of Jamaica', available at:

http://www.cvccoalition.org/sites/default/files/SWAJ_CVC-COIN\%20Profile_Final_ 28February2016.pdf [accessed 8 March 2019].

Taylor, F. (2003), To Hell with Paradise: A History of the Jamaican Tourist Industry (Pittsburgh, PA, University of Pittsburgh Press).

Trafficking Victims Protection Act (2000) (Washington, DC, US Government Printing Office). https://www.govinfo.gov/content/pkg/BILLS-106hr3244enr/pdf/BILLS-106hr3244enr.pdf

UN (2000), Protocol to Prevent, Suppress and Punish Trafficking in Persons Especially Women and Children, Supplementing the United Nations Convention Against Transnational Organized Crime, United Nations Human Rights Office of the High Commissioner. https://www.ohchr.org/en/ProfessionalInterest/Pages/ProtocolTraffickingInPersons.aspx 
UN (2010), 'UN Special Rapporteur Presents Preliminary Findings on His Mission to Jamaica', United Nations Human Rights Office of the High Commissioner, 10 February.

https://newsarchive.ohchr.org/EN/NewsEvents/Pages/DisplayNews.aspx?NewsID=9834\&

LangID=E [accessed 8 March 2019)]

UN (2015), 'Transforming Our World: The 2030 Agenda For Sustainable Development', A/RES/70/1. https://sustainabledevelopment.un.org/content/documents/21252030 $\% 20$ Agenda $\% 20$ for $\% 20$ Sustainable $\% 20$ Development $\% 20$ web.pdf

UNICEF (2004), 'Launch of "Code of Conduct" for Travel Industry to Protect Children from Sex Tourism', 21 April. https://www.unicef.org/media/media_20445.html

UNODC (2018), 'Jamaica Joins UNODC's Blue Heart Campaign to End Human Trafficking', United Nations Office on Drugs and Crime, 5 April.

https://www.unodc.org/unodc/en/frontpage/2018/April/jamaica-joins-unodcs-blue-heart-campaignto-end-human-trafficking.html

US State Department (2017), 'Trafficking in Persons Report June 2017, Jamaica Country Narrative'. https://www.state.gov/wp-content/uploads/2019/02/271339.pdf

Walcott, R. (2009), 'Queer Returns: Human Rights, the AngloCaribbean and Diaspora Politics', Caribbean Review of Gender Studies, 3(4): 1-19.

Walk Free Foundation (2014), 'Tackling Modern Slavery in Supply Chains: A Guide 1.0'. https://www.cips.org/Documents/Knowledge/Procurement-Topics-and-Skills/4-SustainabilityCSR-Ethics/Sustainable-and-Ethical-Procurement/tackling-modern-slavery-in-modern-supplychains.pdf

West, K. \& Cowell, N. (2014), 'Predictors of Prejudice Against Lesbians and Gay Men in Jamaica', The Journal of Sex Research, 52(3): 296-305. https://doi.org/10.1080/00224499.2013.853725

Williams, E. (1961), Capitalism and Slavery (New York, Russell and Russell).

Wong, A. (2015), 'Caribbean Island Tourism: Pathway to Continued Colonial Servitude', Études caribéennes, August-December: 31-2. https://journals.openedition.org/etudescaribeennes/7524; https://doi.org/10.4000/etudescaribeennes. 7524

World Travel and Tourism Council, (2015), 'Jamaica: Benchmarking Report 2015'. http://www.caribbeanhotelandtourism.com/wp-content/uploads/data_center/destinations/JamaicaWTTC-BenchmarkingReport2015.pdf [accessed 8 March 2019].

World Travel and Tourism Council (2017), 'Travel \& Tourism Economic Impact 2017: Jamaica', https://www.wttc.org/-/media/files/reports/economic-impact-research/countries-2017/jamaica 2017.pdf [accessed 8 March 2019].

Notes on the authors:

Katie Cruz is a Lecturer in Law at the University of Bristol Law School. She is a socio-legal scholar who researches the relationship between injustice, rights, and the law in the context of sex work, sexual exploitation, and sex tourism. She is a co-ordinating editor for the journal Feminist Legal Studies.

\section{Recent publications:}

Cruz, K., (2018), 'Beyond Liberalism: Marxist Feminism, Migrant Sex Work, and Labour Unfreedom', Feminist Legal Studies, 26(1): 65-92. https://doi.org/10.1007/s10691-018-9370-7

Hardy, K. \& Cruz, K. (2018), 'Affective Organizing: Collectivizing Informal Sex Workers in an Intimate Union', American Behavioral Scientist, 63(2): 244-61.

https://doi.org/10.1177/0002764218794795 
Julia O'Connell Davidson is Professor of Social Research at the University of Bristol. Her research critically interrogates the concepts of 'trafficking' and 'modern slavery' and she currently holds an ERC Advanced Grant that upturns conventional discourse on modern slavery to explore the problem of freedom for marginalised populations in the contemporary world.

\section{Recent publications:}

O'Connell Davidson, J. (2015), Modern Slavery: The Margins of Freedom (London, Palgrave Macmillan). Brace, L. \& O'Connell Davidson, J. (2018), Revisiting Slavery and Antislavery (London, Palgrave Macmillan). https://doi.org/10.1007/978-3-319-90623-2

Jacqueline Sanchez Taylor is a Lecturer in Sociology at the University of Leicester. Her research interests span sex tourism to the Global South, cosmetic surgery tourism, and beauty and cosmetic surgery. Her focus is on contested commodities (blackness, sexuality, breasts) and the social relations of power that surround informal markets in which bodies are commodified.

\section{Recent publications:}

Sanchez Taylor, J. (2012), 'The Power of Breasts: Gender, Class and Cosmetic Surgery', Women's Studies International Forum, 35(6): 458-66. https://doi.org/10.1016/j.wsif.2012.09.003

Sanchez Taylor, J. (2006), 'Female Sex Tourism: A Contradiction in Terms', Feminist Review, 83(1): 42-59. https://doi.org/10.1057/palgrave.fr.9400280

To cite the article: Katie Curz, Julia O'Connell Davidson, and Jacqueline Sanchez Tayor (2019), 'Tourism and sexual violence and exploitation in Jamaica: contesting the 'trafficking and modern slavery' frame', Journal of the British Academy, 7(s1): 191-216.

DOI https://doi.org/10.5871/jba/007s1.191

This article is licensed under a

Creative Commons Attribution-NonCommercial-NoDerivs 4.0 Unported License.

Journal of the British Academy (ISSN 2052-7217) is published by

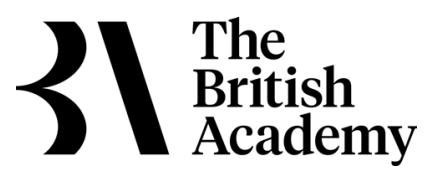

10-11 Carlton House Terrace, London, SW1Y 5AH

www.thebritishacademy.ac.uk 